\title{
1 Stratigraphy, sedimentology and structure of the Jurassic (Callovian to \\ 2 Lower Oxfordian) succession at Castle Hill, Scarborough, North \\ 3 Yorkshire, UK
}

4

5 John H. Powell* \& James B. Riding

6 British Geological Survey, Environmental Science Centre, Keyworth, Nottingham NG12 5GG, UK

$7 \quad *$ Correspondence: jhp@bgs.ac.uk

8

9 Abstract: Site investigation borehole cores and temporary shaft exposures at the Toll House Pumping Station shaft site, Castle Hill, Scarborough, North Yorkshire, have revealed new data on the Callovian to Lower Oxfordian (Jurassic) succession. The condensed transgressive marine unit, the Lower Callovian Cornbrash Formation, rich in berthierine ooids and abundant shelly fossils, and the attenuated Cayton Clay Formation represent the Early Callovian marine transgression that flooded the low-gradient alluvial plain which is represented by the underlying Scalby Formation. The Callovian Osgodby Formation (Red Cliff Rock and Langdale members) is an extensively bioturbated, silty sandstone with abundant berthierine-pyrite ooids in the lower part. It was deposited in lower- to upper-shoreface settings. Slow sedimentation rates, with long sediment residence time, resulted in a diverse ichnofauna and a high bioturbation index. Framboidal pyrite ooids in the lower Osgodby Formation sandstones are interpreted as being formed in anoxic lagoons in the nearshore zone; ooids were subsequently swept offshore during storm surge-ebb events. Cold water dinoflagellate cysts of Boreal affinity such as Gonyaulacysta dentata in the lower part of the Oxford Clay Formation indicate an Early Oxfordian age. This is confirmed by the presence of the zonal ammonite species Quenstedoceras mariae and is consistent with a relatively cold, but warming, palaeoclimate at this time. Shaft excavations revealed a new major fault, the Toll House Fault, which is interpreted to be a splay fault bifurcating off the main Castle Hill Fault. Together, the Toll House and Castle Hill faults form the western bounding faults of the Peak Trough, a graben-like structure that extends northwards, offshore.

\section{Received ; accepted}

Recent engineering works by Arup for Yorkshire Water Services at Scarborough, North Yorkshire, have been aimed at increasing storm water storage capability and improving the quality of the associated discharges, so that Scarborough's beaches can achieve an 'Excellent' standard as defined in the revised EU Bathing Water 
Directive. The results of a study by the British Geological Survey (BGS), which carried out a 'Geological Watching Brief' on behalf of Arup for the Scarborough Revised Bathing Water Directive works at the Toll House Pumping Station shaft site, Scarborough (Powell \& Riding 2013), are summarized in this paper.

The Toll House site constitutes part of a geological Site of Special Scientific Interest (SSSI) extending southwards along the cliff from North Bay to South Toll House Cliff [National Grid References ${ }^{5} 04800{ }^{4} 89300$, $\left.{ }^{5} 05100{ }^{4} 89400,{ }^{5} 04600{ }^{4} 89200,{ }^{5} 04800{ }^{4} 89200\right]$, as designated in 1992 by Natural England (Fig. 1). The designated site required geological monitoring, logging and assessment of site investigation borehole cores and a deep shaft (to -20 m OD) at Toll House. The Toll House shaft site $\left({ }^{5} 05209.71{ }^{4} 88927.96\right)$ is located on the south-east side of Castle Hill below Castle Cliff (British Geological Survey 1998a, b). The site studied included the main shaft for the new Toll House Pumping Station, which has a storm water capacity of $4000 \mathrm{~m}^{3}$, and an adjacent connection chamber located a few metres to the south. The site lies immediately to the north of the well-known South Toll House Cliff locality (Page in Cox \& Sumbler 2002), which exposes the upper part of the Osgodby Formation (Langdale and Hackness Rock members) overlain by the Oxford Clay Formation (Fig. 2). In this paper we describe the stratigraphy, sedimentology and ichnofauna of the succession proved in siteinvestigation boreholes and from temporary exposures, logged sequentially, during the sinking the shaft. We relate our findings to the SSSI site at Toll House and discuss the stratigraphical and sedimentological significance of the new findings in a regional context. New biostratigraphical information is provided on the succession, based on palynology and sparse ammonites. Finally, the study has proven the presence of the newly named Toll House Fault east of Castle Hill, which is part of the Peak Fault (Trough) structure.

The paper is dedicated to the late Robert Knox (see Obituary, Proceedings of the Yorkshire Geological Society, Vol. 59, pp. 261-262, doi:10.1144/pygs2013-342), a former editor of this journal whose research on the Jurassic of the Cleveland Basin and the North Sea was celebrated in a meeting of the Yorkshire Geological Society at the offices of the British Geological Survey, Keyworth, Nottingham, U.K., in March 2014. His doctoral research and publications on the Middle Jurassic, onshore, especially the origin of ooidal ironstones in the Eller Beck Formation (Knox 1969, 1970) is significant with regard to berthierine and framboidal pyrite ooids described in this paper.

\section{The geology of Castle Hill}


Castle Hill is a downfaulted (to the east) outlier of Middle and Upper Jurassic strata, which forms a promontory separating South Bay from North Bay at Scarborough (British Geological Survey 1998a, b). Major faults, with up to $80 \mathrm{~m}$ displacement, downthrow Upper Jurassic rocks against Middle Jurassic rocks, but the structure is complicated by two splay faults that bring the Middle Jurassic rocks (Scalby Formation) and the Cornbrash Formation marker bed high up in the cliff against the Oxford Clay Formation to the to the east (Fig. 1). The shaft excavation also proved a previously unknown fault (Toll House Fault) trending c. $350^{\circ} \mathrm{N}$, sub-parallel to Marine Drive, which downthrows the Oxford Clay and Cornbrash formations c. $15.5 \mathrm{~m}$ to the east, thus defining the eastern margin of Castle Hill (see Structural geology below).

The general structure of Castle Hill is a shallow syncline plunging to the east (Fig. 1), with higher dips (c. $5^{\circ}$ to $\left.8^{\circ} \mathrm{NNE}\right)$ at South Toll House Cliff, and to the north end of Castle Hill (c. $\left.5^{\circ} \mathrm{SSE}\right)$. The anomalously high structural dip seen in the Osgodby Formation at South Toll House Cliff (Fig. 2) is now considered to be due to fault drag on the previously unrecorded Toll House Fault. The stratigraphically highest beds exposed on the summit of Castle Hill comprise the lower part of the Hambleton Oolite Member (Coralline Oolite Formation, Corallian Group; Wright 1983). These relatively hard beds have protected Castle Hill from erosion. In a regional context, the faults defining Castle Hill form part of the NNW-trending Peak Trough and associated faults that have been shown to be active, in the offshore sector east of Whitby, since the Triassic (Milsom \& Rawson 1989).

The steep slopes of Castle Hill cliff between South Toll House Cliff and the north end of the promontory are subject to landslip in the form of rockfall and scree derived from the jointed and fractured faces of the Lower Calcareous Grit and the Coralline Oolite formations, which overlie the softer Oxford Clay Formation. Fallen blocks and scree material, probably deposited during late Pleistocene to Holocene erosion of the palaeocliff, were penetrated up to $8 \mathrm{~m}$ below the ground surface in the site investigation boreholes sub-parallel to Marine Drive. Significant new geological observations and interpretations have arisen from the study and are summarized herein. They include new information on the sedimentation and biostratigraphy of the Callovian to Lower Oxfordian succession and the structural geology of Castle Hill. Further details, including core photographs, are in Powell \& Riding (2013).

\section{Geological importance of the Toll House SSSI site}


The geological and historical significance of the Toll House SSSI site (also known as South Toll House Cliff) is due to the excellent current, and formerly more extensive, exposures of the sedimentary rocks encompassing the Upper Callovian Stage and the Lower Oxfordian Substage (Wright 1968, 1977). At outcrop, the upper part of the Osgodby Formation comprises the Langdale Member (sandstone) (Coronatum Zone), which forms a small cliff $\left[{ }^{5} 05150{ }^{4} 88850\right]$ north-west of Toll House, capped by the Hackness Rock Member (Athleta Zone and Lamberti Zone), a harder iron-rich (berthierine ooidal) calcareous sandstone that forms a prominent ledge (Fig. 2). The overlying Oxford Clay Member (Mariae Zone, Lower Oxfordian) is also exposed, although poorly as it is largely grassed over. The stratigraphy and sedimentology of this section has been studied by many authors. It has yielded biostratigraphically important ammonite specimens, some of which represent type specimens now located in museums (Page in Cox \& Sumbler 2002), and it includes the Callovian-Oxfordian stage boundary.

The beds at this locality dip at about $5-8^{\circ} \mathrm{NNE}$ so that the same succession was encountered in the site investigation boreholes and in the shaft itself. Consequently, the engineering works offered a valuable opportunity to record, describe and study the same succession, at depth, where the rocks are relatively unweathered. Perhaps more significantly, the opportunity to study the lower part of the succession, as revealed by the boreholes (to $c .40 \mathrm{~m}$ depth) and in the shaft, afforded the first opportunity to study this part of the succession since the mid $19^{\text {th }}$ century, prior to the construction of Marine Drive and more recent rock armouring of lower cliff and foreshore below the road. It was these former exposures of the lower part of the Osgodby Formation that enabled the pioneering geologists, William Smith and his protégé and nephew John Phillips, to understand the geology of Scarborough in its regional context. Following on from Smith's early geological map of Yorkshire, Phillips refined the geology and published (1829-1832) an elegant cross-section of the Yorkshire coast, including much detail of the Toll House to Castle Hill section (Fig. 3), which shows clearly the Osgodby Formation (then known as the 'Kelloway Rock') dipping to the north-east below the overlying Oxford Clay. To the north of Castle Hill, Phillips also illustrated the 'Cornbrash' and 'Upper Shales and Sandstone' (now Scalby Formation) below the 'Kelloways Rock'.

Victorian geologists were keen collectors of ammonites and other shelly fauna, such as bivalves and belemnites, from these rocks, in order to establish a biostratigraphical zonation that would allow correlation of the Yorkshire succession with coeval rocks in central and southern England (Young \& Bird 1822; Leckenby 1859; Wright, 1860; Huddleston 1876). These ammonite schemes were later refined by Brinkmann (1926), Buckman (19091930, 1913) and commented on by Arkell $(1933,1945)$, thereby establishing that the Osgodby Formation 
116 (sandstone) of the Cleveland (Yorkshire) Basin is broadly equivalent to the mudstones of the Lower and Middle

117 Oxford Clay Formation of central and southern England, and furthermore, that silt and mud only reached the

118 area of the Tabular Hills (Scarborough) in Early Oxfordian times (Wright 1968). Consequently, the Oxford Clay

119 Formation at Castle Hill is equivalent to the upper unit, the Weymouth Member, of the Oxford Clay Formation

120 of southern England (Fox-Strangways 1892; Fox-Strangways \& Barrow 1915; Cox et al. 1993).

121 More recently, detailed and wide ranging studies by Wright $(1968,1977,1978)$ have revealed a more complex

122 sedimentary history during Callovian times. Based on detailed analysis of the ammonites and other shelly faunas

123 and logging of the Osgodby Formation, Wright (1968) showed that there are significant time gaps and erosional

124 events (hiatuses) separating the three members of the Osgodby Formation (in upward sequence, the Kellaways

125 Rock Member [now the Red Cliff Rock Member], Langdale Member and Hackness Rock Member) (Fig.4).

126 Wright's stratigraphical studies were further refined by Cox (1988) and Page (1989), the latter author

127 introducing a number of new lithostratigraphical terms. Part of the Upper Jurassic succession (Coralline Oolite

128 Formation) on the north side of Castle Hill and the southern end of North Bay was described in Rawson \&

129 Wright (2000, itinerary 7). A sedimentological study of the Hackness Rock Member, based on the Toll House exposures (Williams 2002), showed that microfacies in this condensed unit represented diverse depositional sub-environments. The South Toll House cliff and adjacent localities were also described in the Middle Jurassic Joint Conservation Review of Great Britain (Page in Cox \& Sumbler 2002), highlighting the scientific importance of the exposures.

\section{Methodology}

\section{Site investigation boreholes}

136 Prior to excavating the Toll House Pumping Station shaft, a number of site investigation boreholes were drilled

137 sub-parallel to Marine Drive in the vicinity of the shaft site and associated engineering works (Fig. 5). In

138 addition, four deep cored boreholes were drilled from the top of Castle Hill and adjacent fault blocks, located to the north-west of the site, to prove the geology below Castle Hill for a projected sewage tunnel that was not taken forward. Borehole records (logged by JHP) dating from the 1980s, for the existing sewage outfall, were also available in the BGS records (Powell 1980; Powell \& Reay 1982).

Four representative borehole cores (BH1-3-02; BH1-3-03C; BH1-3-04; and BH2-3-01) (Fig. 5) were slabbed, cleaned and logged by JHP. High resolution digital photographs were taken of the slabbed core (see Powell \& 
Riding 2013 for details). The core was sampled for micropalaeontology and petrology by JBR and JHP. Non-

curated halves of the cores were split parallel to the bedding planes to obtain macrofossil specimens and representative examples of trace fossils. Some of the core was not available because selected lengths had been extracted for engineering geology testing prior to geological investigations by BGS. However, the four curated boreholes provide overlapping representative core for the Callovian to Lower Oxfordian succession.

\section{Shaft investigations}

Geological investigations during sinking of the shaft were limited to five visits of around 45 minutes' duration. This enabled sampling of the rock from the base (floor) of the shaft and c. $0.75 \mathrm{~m}$ height of exposed rock in the wall adjacent to the shaft cutting shoe. Ongoing excavation of the shaft by rock hammer meant that, at times, it was difficult to determine sedimentary bedding, but structural measurements were taken where feasible. In addition to the samples taken by JHP, Helen Miles (Arup) collected ad-hoc samples from the base of the shaft on a weekly basis; these were backed up by a digital photographic record that proved to be important when contrasting lithologies were exposed either side of the new Toll House Fault (see Structural geology). The fault line was surveyed by theodolite during the excavations.

Hand specimen samples taken by JHP were cleaned and curated at BGS. The final samples were taken on $14^{\text {th }}$ May 2013 at -20 m OD depth, prior to final cementing of the shaft floor. The cores, macrofossil and microfossil specimens and the palynological slides are curated at the National Geological Repository, BGS, Keyworth, Nottingham NG12 5GG. Additional borehole information for the wider Castle Hill site was made available by Arup, and has facilitated a better understanding of the stratigraphy and structural geology of the area.

\section{Lithostratigraphy}

The Callovian to Lower Oxfordian succession (Fig. 4) is best represented in Borehole 1-3-03C, which proved the succession from the Oxford Clay Formation down to the Cornbrash Formation and topmost Scalby Formation (Figs 4, 5). This was supplemented by three additional boreholes that proved critical parts of the succession (Table 1). The location of the boreholes and summary lithological and gamma-ray logs are shown in Fig. 5; some of the coloured stratigraphical boundaries shown in these logs have been reinterpreted following detailed analysis of the core. The curated boreholes, located from south to north, with the formations penetrated, are listed in Table 1. 
171 The stratigraphical succession proved in the boreholes is described below in ascending order. This account is

172 based primarily on the most complete core, BH 1-3-03C (Figs 5, 6), except where noted. Depths refer to drilled 173 depths from ground surface in BH1-3-03C, except where noted for other boreholes (Figs 6-9). Borehole cores are illustrated in Figures 10, 12, 15 and 18.

\section{Scalby Formation (Long Nab Member) (Middle Jurassic: Bathonian): 41.55-41.62 m}

176

177

Only the topmost $0.07 \mathrm{~m}$ of the Scalby Formation (Long Nab Member) was proved at the base of the borehole, from 41.55-41.62 m. It consists of pale grey, non-calcareous mudstone with sparse plant fragments. Borehole 13-04 (Fig. 9) proved a thicker succession from 34.80-35.60 m, consisting of pale grey mudstone with sparse plant fragments overlain by structureless, fine-grained, non-calcareous sandstone. The boundary with the overlying Cornbrash Formation is irregular and erosional.

The structureless nature of the sandstone suggests pedogenic alteration, and the presence of finely comminuted plant fragments indicates deposition in a non-marine, alluvial floodplain environment. In contrast to the boundary seen at outcrop in Cayton Bay, to the south, there is no evidence of downward penetrating Thalassinoides burrows at the base of the Cornbrash Formation (Wright 1968; Riding \& Wright 1989; Powell 2010).

\section{Cornbrash Formation (Middle Jurassic: Callovian) 40.80-41.55 m}

The Cornbrash Formation is thinner in these boreholes $(0.75-0.95 \mathrm{~m})$, compared to reported outcrops in North Bay (1.18 m; Wright 1977; Page in Cox \& Sumbler 2002). The lower part (0.22 m) comprises brown and grey sideritic calcareous mudstone with coarser bioclastic burrow-fill, comminuted shell fragments and sparse oysters (Ostrea sp.) (Fig. 10). This passes up to pale grey, medium-grained sandstone with berthierine ooids and rounded intraclasts of black calcareous mudstone with small berthierine ooids and small shell fragments; sparse encrusting serpulid worms and bryozoans are present. The uppermost $0.30 \mathrm{~m}$ consists of light grey to medium light grey, bioclastic limestone with dispersed berthierine ooids. The rock fabric is highly bioturbated (Thalassinoides); other burrows are backfilled with grey calcareous mudstone (siderite); oysters (Ostrea sp.; Lopha sp.) are common along with Trigonia sp. and other bivalve fragments. Fragmented ammonite shells and belemnite guards are occasionally present. The upper boundary with the Cayton Clay Formation is poorly preserved in $\mathrm{BH} 1-3-03 \mathrm{C}$, but is sharp in $\mathrm{BH} 1-3-04$. 
(Fig. 11), and confirm an early Callovian age. Berthierine ooids are commonly replaced by ferroan calcite, although much of the shell material is preserved as non-ferroan calcite. Sub-angular quartz is present, and pyrite spheres or framboids (so-called 'raspberry-like' clusters) are common in the sparry calcite matrix.

\section{Cayton Clay Formation (Middle Jurassic; Callovian: Herveyi Zone) 40.60-40.80 m}

This thin unit is poorly preserved in the boreholes, probably because of its soft mudstone lithology which is prone to re-drilling or flushing. However, fragments of brownish grey mudstone with light grey, very finegrained sandstone with micaceous siltstone laminae were preserved in $\mathrm{BH} 1-3-03 \mathrm{C}$ over an interval of about $0.20 \mathrm{~m}$. A similar thickness $(0.25 \mathrm{~m})$ was proved in BH 1-3-04. No macrofauna was recovered from the core.

The Cayton Clay Formation (formerly known as 'Shales of the Cornbrash') is also reported to be poorly exposed in North Bay (Wright 1977; Page in Cox \& Sumbler 2002) where the basal $0.10 \mathrm{~m}$ of dark grey, silty clay has yielded abundant bivalves including Meleagrinella braamburiensis (Phillips) and Modiolus bipartitus (J. Sowerby) (Page 1989).

\section{Osgodby Formation (Middle Jurassic: Callovian: Koenigi to Lamberti zones) 11.70-40.60 m} Lamberti zones of the Callovian Stage, spanning about 3.5 million years. Formerly known as the Kelloways Rock (Phillips 1829-1832) and later as the Kellaways Rock (see Arkell 1933 for discussion), it was formally defined by Wright (1968), who subdivided the formation into three members, in upward sequence, the Kellaways Rock Member, the Langdale Member and the Hackness Rock Member. Page (1989) re-named the lowest member as the Red Cliff Rock Member to distinguish it from the Kellaways Rock of southern England. three constituent members, which are locally separated by intraformational depositional hiatuses or erosion surfaces. The succession at Toll House, Castle Hill, is shown in figure 5 of Wright (1968), but this is based largely on an earlier description of the foreshore and lower cliff by Huddleston (1876) prior to the construction of Marine Drive. The figure was supplemented by a description based on the succession seen in the cliff below Rutland Terrace in North Bay (Wright 1968, section 4). Consequently, there is no wholly reliable extant section for the Osgodby Formation at the South Toll House Cliff site. The new cored borehole records are therefore highly significant, especially in light of the discovery of the new Toll House Fault, which downthrows the 
Osgodby Formation to the east (see below), thereby possibly introducing a repetition of the strata as formerly

227

228

229

230

231

232

233

234

235

236

237

238

239

240

241

242

243

244

245

246

247

248

249

250

251

252

253 seen in the Toll House foreshore cliff in the $19^{\text {th }}$ century. With this possibility in mind, the section redrawn by Wright (1968, fig. 5, based on Huddleston 1876) differs in detail from the Osgodby Formation succession proved in the boreholes. For instance, the feature-forming, fine- and medium-grained sandstone beds, c. $5.8 \mathrm{~m}$ thick, which include a medium-grained sandstone bed with ammonites in the upper part of the Red Cliff Rock Member, have not been identified in the borehole cores.

The lower boundary with the Cayton Clay Formation is sharp. The basal Osgodby Formation sandstone is fineto medium-grained with ripple cross-lamination and thin clay drapes; in the basal $0.20 \mathrm{~m}$, a sideritized ammonite was found at $40.45 \mathrm{~m}$ depth, and calcite belemnite guards are occasionally present. The overlying sandstone is brownish grey and medium-grained with abundant amorphous organic matter and dispersed black, concentric pyrite ooids up to $0.5 \mathrm{~mm}$ in diameter (Figs 13,14$)$. A characteristic feature of the core is the high bioturbation index, with a range of trace fossil burrows that include Teichichnus, Phoebichnus, Siphonites, Planolites, Skolithos, Diplocraterion and Chondrites (Fig. 12). Intensive burrowing often shows sequential tiering (Howard 1985; Gowland 1996; Taylor \& Gawthorpe 1993; Taylor et al. 2003), i.e. reworking or reburrowing across previously formed burrows. Consequently, the original primary sedimentary structures (e.g. ripples, cross-lamination and bedding) are generally destroyed. Exceptions to this are intervals between 38.10 and $38.20 \mathrm{~m}$, where discrete parallel lamination is preserved in sandstone interbedded with siltstone, and at $34.45 \mathrm{~m}, 34.48 \mathrm{~m}$ and $32.65 \mathrm{~m}$. Black pyrite ooids become more common upwards from about $34.50 \mathrm{~m}$. Ovoid, medium-grey siderite concretions, $0.08 \mathrm{~m}$ in diameter, are present at $34.80 \mathrm{~m}$ and $34.48 \mathrm{~m}$ (Fig. 12). A gradational upward decrease in overall grain size occurs at about $31.20 \mathrm{~m}$ depth, also accompanied by fewer dispersed pyrite ooids. This level may mark the boundary between the Red Cliff Rock Member and the overlying Langdale Member. However, the change is gradational, and the feature-forming (better cemented?) beds marking this boundary in the Rutland Terrace section, north of Castle Hill (Wright 1968, fig. 5), were not seen. If this gradational boundary, as seen in the core, represents the true boundary between these members, then measured thickness $(9.4 \mathrm{~m})$ from the top of the Cayton Clay Formation is not significantly different from the $11.3 \mathrm{~m}$ thickness shown in Wright's figure, especially as the lower boundary, at outcrop, appears to be an estimate.

Pyrite ooids have not previously been reported from the lower part of the Osgodby Formation. It may be that berthierine ooids described by previous authors, which are present in the Cornbrash Formation and the Hackness 
Rock Member (Wright 1978), have been misidentified, especially as the cores provide unweathered fresh material in contrast to material that might be oxidized at outcrop. Pyrite ooids are dispersed within the bi-modal quartz sandstone (Figs 13,14). They comprise concentrically zoned laminae made up from individual pyrite clusters or framboids, often seeded around a quartz grain (Fig. 13). The outer cortex often appears irregular or 'squeezed' between adjacent quartz grains (Fig. 14). Individual or irregular clusters of pyrite framboids are also present, dispersed in the matrix between the sand grains. Quartz grains are generally sub-angular and of bimodal grain-size distribution. In hand specimen, the core appears as grey or pale grey clusters ('augen') consisting of purer quartz sand representing backfilled quartz-rich burrows surrounded by pale brown distorted laminae rich in amorphous organic matter (Fig. 14).

The upper part of the sandstone-dominated Osgodby Formation, equivalent to the Langdale Member, consists of very light grey to light grey, slightly micaceous, fine- to medium-grained, slightly calcareous sandstone with medium grey wispy mudstone laminae (Fig. 15). Where intersected by fractures, it weathers to pale yellowishorange sandstone. It becomes more calcareous above $c .17 \mathrm{~m}$ depth, close to the boundary with the overlying Hackness Rock Member. The Langdale Member is extensively bioturbated, but the sand grain-size is slightly finer and is more unimodal (better sorted) than in the underlying Red Cliff Rock Member. The ichnofauna is also diverse, but the upper sandstone has a higher proportion of vertically orientated burrows, especially the ichnogenera Teichichnus, Rhizocorallium, Skolithos and Diplocraterion, as well as ubiquitous Chondrites and Siphonites (Fig. 15). Tier structures showing repeated, often cross-cutting burrowing phases are common, and the sequential ordering from small Chondrites $>$ Teichicnus $>$ Siphonites $>$ Skolithos $>$ Asterosoma is present (Howard 1985; Gowland 1996). Shelly lags comprising small, thin-shelled bivalves and brachiopods, together with small wood fragments, are present at $19.30 \mathrm{~m}$ and $14.50 \mathrm{~m}$ depth, the latter $1.5 \mathrm{~m}$ below the base of the overlying Hackness Rock Member. Calcite belemnite guards are occasionally present, but no ammonites were seen.

The Hackness Rock Member (11.70 m-13.00 m), 1.3 m thick at the top of the Osgodby Formation, provided a useful marker level when interpreting the borehole cores and gamma-ray logs and during shaft excavation, particularly with respect to determining the throw on the Toll House Fault. It is also the main feature of the extant South Toll House Cliff SSSI site (Fig. 16). In BH 1-3-03C, the boundary with the underlying Langdale Member is gradational over $0.36 \mathrm{~m}(13.06-12.70 \mathrm{~m})$; the boundary interval is marked by an upwards? increase in the bioturbation index and carbonate content. The fine-grained, slightly calcareous sandstone is pale 
yellowish brown (weathered oxidized iron) close to fractures, passing to greyish orange, with pervasive burrow mottling. Occasional thin-shelled bivalves, brachiopods and belemnite guards are present at $12.70 \mathrm{~m}$ and 12.50 m. Ichnogenera include Diplocraterion, Rhizocorallium, Teichichnus, Planolites, Siphonites, Chondrites and small diameter Thalassinoides. Berthierine ooids are less common near the base, and are concentrated within the burrow fill (Fig. 17). The upper part of the unit, where unweathered, is light bluish grey, calcareous fine-grained sandstone passing to sandy limestone, with intensive burrowing and relatively large berthierine ooids, up to 1 $\mathrm{mm}$ diameter, scattered in clusters, depending on the intensity of bioturbation. Berthierine ooids are white where altered to ferroan calcite. Patches of siderite cement are common, often infilling burrows and whole bivalve shells. Macrofossils include bivalves, such as the oysters Ostrea sp. Lopha sp. and Gryphaea sp., small rhynchonellid brachiopods, belemnite guards, ammonites, gastropods and wood fragments. Finely comminuted shell fragments are present in the upper part of the unit. In BH 2-3-01, the base of the Hackness Rock Member is marked by a thin shell bed at $22.15 \mathrm{~m}$ depth, probably representing a storm-deposited bed, above a scoured surface. This shell bed was also seen at the base of the member in BH 1-3-02 at $15.46 \mathrm{~m}$ depth. The shell bed is probably the same as that seen at outcrop in the South Toll House Cliff (Fig. 16).

In thin section (Fig. 17), the Hackness Rock Member consists of bimodal, subangular quartz, similar to the underlying sandstones, but with a higher proportion of berthierine ooids, up to $1 \mathrm{~mm}$ in diameter. In weathered material near to fractures, the ooids are generally altered to white calcite (in hand specimen). However, in stained thin section of these weathered zones, the inner laminae of berthierine and associated pyrite is occasionally preserved (Fig.17); outer laminae are altered to ferroan calcite micro-spar, which also forms much of the cement matrix.

The upper part of the Hackness Rock Member was poorly exposed at -1.5 m OD in the south-east of the shaft. The blue grey, burrow-mottled, berthierine ooid-rich calcareous sandstone yielded shelly fossils that include belemnites and bivalves (Gryphaea sp.). At -3.0 m OD, the whole of the Hackness Rock Member was exposed, including the upper boundary with the Oxford Clay. Excellent exposures of the Hackness Rock Member included in-situ clusters of the bivalve Gryphaea sp. (Fig. 20), burrow mottled berthierine ooid rich sandstone with bivalves and the ammonite Kosmoceras sp.

\section{Oxford Clay Formation (Upper Jurassic; Lower Oxfordian; Mariae Zone) 8.89-11.70 m}

The Oxford Clay Formation is the highest bedrock unit proved in the boreholes and shaft excavations at the Toll House Site. Only the upper part of the Oxford Clay Formation of southern England, the Weymouth Member, is 

about 163.5 Ma (Gradstein et al. 2012). Despite its lithological epithet, the formation at Castle Hill is represented by a calcareous siltstone lithology, in contrast to the softer claystone of southern England. The lower part, and the boundary with the underlying Hackness Rock Member, can be seen in the South Toll House Cliff, but is mostly grassed over. Better exposures can be seen higher in the Castle Hill cliff to the north of the site (Figs 1,2). The relatively steep structural dip seen in the South Toll House Cliff brings the Oxford Clay Formation down to ground level at the shaft site and farther north (Fig. 2), although the site investigation boreholes along Marine Drive generally penetrated rockfall and scree material derived from the upper part of the cliff (Corallian Group) overlying the bedrock (see below).

The boundary with the underlying Hackness Rock Member is generally sharp and planar (Fig. 18), but in BH 13-02 the boundary is irregular with upward-domed convolute structures in the basal $0.06 \mathrm{~m}$, comprising pale grey and dark grey, mottled calcareous siltstone and claystone. Similar contorted laminae occur in the basal siltstone in $\mathrm{BH}$ 2-3-01. The lowermost $0.15 \mathrm{~m}$ of the Oxford Clay Formation in $\mathrm{BH} 1-3-03 \mathrm{C}$ comprise light brownish grey siltstone and silty mudstone with faint parallel lamination and pervasive, but poorly defined, 5 mm diameter burrows together with scattered small berthierine ooids and sparse wood fragments (Fig. 18). Above $11.55 \mathrm{~m}$ depth, the formation comprises light grey, calcareous siltstone, with a generally massive or faintly laminated texture. The absence of lamination is attributed to pervasive but lithologically poorly contrasted burrows that have homogenized the sediment. Thin-shelled ammonites, including the zonal species Quenstedoceras mariae, and calcite belemnite guards are present, along with platy fragments of fish or marine reptiles and sparse thin-shelled bivalves. A characteristic feature of these lower beds is the presence of discrete circular, meandering, pyritized burrows parallel to bedding; they have a dark pyritic fill and a yellow- brown limonitic outer cortex (Fig. 19). Some examples show unusual single-sided protuberances (Fig. 19). In thin section, cross-sections through the burrows show a dense pyrite core surrounded by a 'halo' of silt-grade particles in which the organic matter is oxidized.

The Oxford Clay Formation was exposed over much of the base of the shaft circumference at -1.5 m OD. Specimens of grey calcareous siltstone were collected, together with fragments of thin-shelled ammonites.

\section{Rock Fall and Scree (Pleistocene to Holocene) 4.20-8.89 m}


342 spiculitic sandstones and ooidal limestones of the Lower Calcareous Grit and Coralline Oolite formations that 343 form the upper third of the Castle Hill cliff (Fig. 1).

344 The rock fall deposits appear to have covered a pre-existing, lower cliff/foreshore slope cut in the Oxford Clay

345 Formation at the Toll House shaft site. This probably occurred as a response to sea-level rise following the last 346 glaciation in Late Pleistocene to Early Holocene times.

\section{Biostratigraphy}

348 Palynology

349 The composite succession cored and sampled in this study generally produced productive palynomorph 350 associations that are indicative of the interval from the Bathonian-Callovian transition to the lowest Oxfordian

351 Stage. Although stratigraphical precision in the Callovian Stage is not at the resolution of the standard 352 (ammonite) zonation, the palynofloras and the palynofacies are consistent with a relatively continuous 353 succession throughout the Cornbrash, Cayton Clay and Osgodby formations. relatively sparse, low diversity palynofloras that are consistent with the Bathonian-Callovian transition and are in agreement with the findings of Riding \& Wright (1989), especially those from borehole 1-3-04. The sample at $41.68 \mathrm{~m}$ in borehole 1-3-03C produced the marine dinoflagellate cysts Ctenidodinium combazii, Impletosphaeridium varispinosum, Meiourogonyaulax caytonensis and Pareodinia ceratophora. The range of Impletosphaeridium varispinosum is latest Bathonian to Early Callovian (Riding 1987; Riding \& Thomas 1992), indicating the age of the sample. Ctenidodinium combazii and Meiourogonyaulax caytonensis are consistent with a latest Bathonian to Early Callovian age.

The Cornbrash Formation is characterized by relatively diverse dinoflagellate cyst floras that indicate an Early Callovian age and an open marine environment of deposition, reflecting the change from the paralic sedimentation in the underlying Ravenscar Group (Scalby Formation) to the open marine conditions of the Callovian. The formation (formerly the Cornbrash Limestone) was sampled in boreholes 1-3-03C and 1-3-04, the samples producing relatively abundant palynofloras. The dinoflagellate cysts recorded comprise 
varispinosum, Korystocysta gochtii, Meiourogonyaulax caytonensis, Mendicodinium groenlandicum,

Nannoceratopsis pellucida, Pareodinia ceratophora, P. halosa, P. prolongata, Rhynchodiniopsis cladophora,

Rigaudella aemula, Sirmiodinium grossii and Tubotuberella dangeardii. This association is consistent with floras 1992), whereas the range tops of Ctenidodinium combazii and Impletosphaeridium varispinosum are in the Early bases and tops of these species thus confirm the Early Callovian age of the Cornbrash Formation.

\section{Cayton Clay Formation} have relatively sparse, low diversity palynofloras. The high levels of amorphous organic matter are consistent with oxygen-poor bottom waters. One sample was collected from the Cayton Clay Formation (formerly 'Shales of the Cornbrash'), at $33.85 \mathrm{~m}$ in borehole 1-3-04. Its palynoflora largely comprises pollen grains such as Callialasporites spp. and Classopollis classoides. Only a single specimen of the dinoflagellate cyst Rhynchodiniopsis cladophora was encountered, the occurrence of which is consistent with a Callovian age (Riding 1992).

The Red Cliff Rock Member was only sampled in borehole 1-3-03C between $40.80 \mathrm{~m}$ and $35.23 \mathrm{~m}$. The three samples produced organic residues that are extremely rich in amorphous organic material, but palynomorphs are sparse. The dinoflagellate cysts recognized include ?Gonyaulacysta jurassica subsp. adecta, indeterminate forms, Korystocysta gochtii, ?Meiourogonyaulax spp., Mendicodinium groenlandicum, Valensiella ovulum and Valensiella spp. The presence of these forms is consistent with significant marine input. This sparse, low diversity dinoflagellate cyst association does not include any biostratigraphically significant forms. However, it 
The Langdale Member is typified by extremely high levels of amorphous organic material, and relatively sparse

397 palynomorph associations. The dinoflagellate cyst assemblages are of moderate diversity, more diverse than in

398 the underlying member, and include Chytroeisphaeridia chytroeides, Ctenidodinium continuum, Ct. ornatum,

399 Escharisphaeridia spp., Fromea tornatilis, Gonyaulacysta jurassica subsp. adecta, Korystocysta gochtii, K.

400 pachyderma, Nannoceratopsis pellucida, Meiourogonyaulax planoseptata, Meiourogonyaulax spp.,

401 Mendicodinium groenlandicum, Pareodinia spp., Rhynchodiniopsis cladophora, Sentusidinium spp.,

402 Surculosphaeridium vestitum, Tubotuberella dangeardii, Valensiella spp. and Wanaea acollaris. These forms

403 are consistent with a fully marine palaeoenvironment.

404 The assemblage is typical of the Callovian (Riding 2005), and in particular the presence of Ctenidodinium

405 continuum, Ct. ornatum and Rhynchodiniopsis cladophora indicate a definite Callovian age (Riding 1992). No

406 Early or Late Callovian markers, such as Ctenidodinium combazii and Wanaea thysanota respectively, were

407 recorded, and this, together with the higher dinoflagellate cyst diversity, suggests a Middle Callovian age.

408 Meiourogonyaulax planoseptata, recorded in sample 41 from the middle part of the Langdale Member in

409 borehole 2-3-1, is characteristic of the Early Callovian of eastern England (Riding 1987), so may represent

410 reworking of Lower Callovian strata. However, it is known from younger strata in Russia (Riding et al. 1999).

411 In summary, the Langdale Member is interpreted as being of probable Middle Callovian age, but there is no

412 palynological evidence for this unit being entirely confined to the Middle Callovian Coronatum Zone (Cope et

413 al. 1980, fig. 8; Cox \& Sumbler 2002, fig. 5.2). Furthermore, there is no palynological evidence for significant

414 hiatuses below and above the Langdale Member.

415 Osgodby Formation, Hackness Rock Member

416 The Hackness Rock Member generally produced productive palynomorph associations. These include relatively

417 abundant and diverse dinoflagellate cyst assemblages, which are consistent with an open marine depositional

418 setting. The floras include Ambonosphaera? staffinensis, Chytroeisphaeridia spp., Ctenidodinium continuum,

419 Ct. ornatum, Endoscrinium galeritum, Escharisphaeridia spp., Fromea tornatilis, Gonyaulacysta jurassica

420 subsp. adecta, Korystocysta spp., Meiourogonyaulax spp., Mendicodinium groenlandicum, Pareodinia spp.,

421 Prolixosphaeridium spp., Rhynchodiniopsis cladophora, Sentusidinium spp., Sirmiodiniopsis orbis,

422 Sirmiodinium grossii, Stephanelytron redcliffense, Surculosphaeridium vestitum, Trichodinium scarburghensis,

423 Tubotuberella dangeardii and Wanaea thysanota. The associations are comparable with existing reports of latest 
424 Callovian dinoflagellate cysts from northwest Europe (e.g. Riding 1982; Berger 1986; Prauss 1989; Riding \& Thomas 1997).

426 The overlapping ranges of Ctenidodinium continuum, Trichodinium scarburghensis and Wanaea thysanota are

427 indicative of a Late Callovian age. The inceptions of Trichodinium scarburghensis and Wanaea thysanota lie in 428 the Athleta Zone, and the range top of Ctenidodinium continuum is close to the Callovian-Oxfordian transition

429 (Woollam 1980; Riding \& Thomas 1992). No Oxfordian index taxa are present. Mendicodinium groenlandicum 430 is especially common in sample 38 (borehole 2-3-1, 21.50 m). An acme of this species is characteristic of the 431 latest Callovian Lamberti Zone (Riding \& Thomas 1997). The key sample is number 21 (borehole 1-3-02, 14.00 m), which yielded Trichodinium scarburghensis and Wanaea thysanota.

434 The Oxford Clay Formation yielded relatively abundant and diverse palynoforas that are consistently rich in 435 marine forms, indicating an open marine depositional setting. The dinoflagellate cyst floras include prominent 436 Gonyaulacysta jurassica subsp. adecta, Rhynchodiniopsis cladophora, Sentusidinium spp., Surculosphaeridium 437 vestitum and Trichodinium scarburghensis. Other forms recorded include Chytroeisphaeridia spp., 438 Compositosphaeridium polonicum, Endoscrinium galeritum, Gonyaulacysta dentata, G. eisenackii, G. jurassica 439 subsp. adecta var. longicornis (large morphotype), G. jurassica subsp. jurassica, Meiourogonyaulax spp., 440 Mendicodinium groenlandicum, Nannoceratopsis pellucida, Pareodinia spp., Prolixosphaeridium spp., 441 Scriniodinium crystallinum, Sirmiodinium grossii, Tubotuberella dangeardii, Wanaea fimbriata and W. 442 thysanota. This assemblage compares well to other records of Early Oxfordian marine microplankton from 443 Europe (e.g. Woollam 1980; Riding \& Thomas 1997; Riding 2005).

444 Certain key dinoflagellate cyst taxa are indicative of an earliest Oxfordian age (Mariae Zone). Specifically, the 445 presence throughout of Gonyaulacysta jurassica subsp. jurassica means that this unit can be no older than the 446 earliest Oxfordian because the range base of this subspecies is in the Mariae Zone (Riding \& Thomas 1992).

447 The range top of the Boreal species Gonyaulacysta dentata is also within the Mariae Zone, and its occurrence is 448 its first record from England (Riding 2012; Riding \& Michoux 2013). Wanaea fimbriata is confined to the Early 449 Oxfordian. Moreover, Gonyaulacysta jurassica subsp. adecta var. longicornis (large morphotype),

450 Scriniodinium crystallinum and Wanaea thysanota are characteristic of the Early Oxfordian (Riding \& Thomas 


\section{Macropalaeontology}

454 Macrofossils were obtained from the split core, including levels above the curated, slabbed core shown in 455 Appendix 1 (Supplementary Data). Additional specimens were collected at the excavated shaft levels. Much of the material is fragmentary, but the following results indicate the presence of the major ammonite zones and in some cases the subzones for the Hackness Rock Member (Osgodby Formation) and the Oxford Clay Formation. The lower two members of the Osgodby Formation, the Cayton Clay Formation and the Cornbrash Formation did not yield diagnostic ammonites.

Osgodby Formation, Hackness Rock Member

Quenstedoceras cf. lamberti (J. Sowerby) was found at -3.0 m OD in the shaft and a Kosmoceras [M] fragment at $-17.0 \mathrm{~m}$ OD, suggesting respectively the Lamberti and Athleta zones.

The ammonites Cardioceras cf. scarburgense (Young \& Bird) at $11.25 \mathrm{~m}$ depth and Quenstedoceras cf. mariae (d'Orbigny) at $11.34 \mathrm{~m}$ in Borehole 1-3-03C indicate the Mariae Zone, Scarburgense Subzone.

Relatively abundant Peltoceras specimens were seen particularly well in Borehole 2-3-1 between $15.10 \mathrm{~m}$ and $18.10 \mathrm{~m}$, and are the Lower Oxfordian forms often referred to Parawedekindia arduennense. Page (1991) assigned them instead to species of Peltoceras (Peltomorphites) such as subtense (Bean) and hoplophorus (Buckman). On the Yorkshire coast (e.g. at Cornelian Bay and Red Cliff), they have been recorded from the Mariae Zone, Praecordatum Subzone, but although they appear to occur at a higher stratigraphical level than the ammonites noted above in Borehole 1-3-03C, without accompanying cardioceratids in Borehole 2-3-1 and more

472 detailed assessment of records elsewhere, subzonal assignment is here left open.

473 Macrofossil determinations for the shaft and boreholes are listed in Appendices 1 and 2 (Supplementary Data).

\section{Sedimentology}

475 The Callovian to Oxfordian succession at Toll House has provided significant new scientific data that help to 476 better understand the sedimentary processes and their response to sea-level and tectonics during the Mid- to Late 

Oxfordian sedimentation in the North Sea, especially the broadly coeval Fulmar Formation (Howard 1985; Taylor \& Gawthorpe 1993; Gowland 1996).

\section{Scalby Formation, Long Nab Member}

The Lower Callovian Cornbrash Formation and underlying Bathonian Scalby Formation were not seen in the shaft excavations, which terminated above this stratigraphical level, but they were proved in Boreholes 1-3-03C and 1-3-04 (Fig.5). In the latter borehole, the Long Nab Member of the Scalby Formation is represented by pale grey, leached sandstone overlying very light grey mudstone with sparse carbonaceous plant fragments.

Sphaerosiderite is present in mudstone lower in the sequence, and is considered, along with the leached structureless nature of the sandstone, to be indicative of pedogenetically altered (humic) floodplain sediments deposited on a low-gradient alluvial plain (Leeder \& Nami 1979; Riding \& Wright 1989; Whyte \& Romano 2006; Powell 2010).

A greater thickness of the Scalby Formation (Long Nab Member) was proved in BH 1-7-10 and BH 2-7-10 on the north-west side of Castle Hill, where these floodplain sandstones and mudstones show a typical 'saw-tooth' gamma-ray profile (Fig. 23); the upper part is also seen in BH 1-3-04 at Toll House. The distinctive gamma-ray low seen at c. 50m depth below the base of the Cornbrash Formation in BH 1-7-10 is probably the Moor Grit Member (sandstone) at the base of the Scalby Formation.

\section{Cornbrash and Cayton Clay formations}

The global sea-level rise during the Herveyi Zone (Early Callovian) is marked by the disconformable, locally erosional boundary at the base of the Cornbrash Formation. In the boreholes, the boundary is irregular over a few centimetres, indicating erosional scouring of the Scalby floodplain during the initial transgression (Fig. 10). This contrasts with a boundary at outcrop in Cayton Bay, where downward penetrating Thalassinoides (crustacean) burrows pipe coarser burrow-fill into soft Scalby Formation mudstones, indicating that the underlying sediments were soft or firm, i.e. unlithified during the marine transgression (Wright 1977; Powell 2010). Although the Cornbrash Formation core is generally fractured, there are sufficient fragments to allow the palaeoenvironment to be established. Iron-rich, sandy limestone was deposited in shallow water lagoons, with the generation of berthierine ooids in oscillating tidal conditions on adjacent highs. Encrusting oysters (Lopha, 
Ostrea) and other bivalves thrived, and are often preserved in-situ, along with brachiopods and serpulid worms.

Free-swimming (nektonic) ammonites, belemnites and calcareous foraminifera were preserved on the sea-floor,

507 but sedimentation rates were low, allowing burrowing organisms such as crustaceans and worms to modify the

508 primary sedimentary structures. Subsequently, during late diagenesis, much of the iron silicate and iron carbonate was altered to ferroan calcite.

510 The Cornbrash Formation marks a major rise in sea-level in Early Callovian times (Herveyi Zone) (Fig. 23),

511 about 164.7 Ma (Gradstein et al. 2012). This marine transgression marks a major sequence boundary and marine

512 flooding surface across the pre-existing, low-gradient alluvial plain of the underlying Scalby Formation. The

513 presence of abundant shallow-water bivalves, including encrusting oysters, together with free-swimming

514 ammonites and belemnites suggest a shallow marine, upper shoreface environment. Abundant berthierine

515 (chamosite) ooids dispersed throughout the limestone and the high bioturbation index (Taylor et al. 2003)

516 indicate slow rates of sedimentation.

517 The soft Cayton Clay Formation is poorly represented in the borehole cores at Toll House, possibly due to core 518 loss or re-drilling. Elsewhere in the region, for instance at Cayton Bay, it is up to $3 \mathrm{~m}$ thick and was assumed to 519 be about this thick near Castle Hill and North Bay (Wright 1968, fig. 5). However, no great thickness is seen in 520 the gamma-ray logs, and the boreholes record, at most, $0.25 \mathrm{~m}$ of dark grey, laminated siltstone and mudstone 521 with grey, fine-grained sandstone laminae.

522 The formation is interpreted as representing the maximum flooding of the Early Callovian transgression. Dark 523 grey, laminated mud and fine sand, and the absence of encrusting oysters, burrows and berthierine ooids in this 524 thin unit indicate deposition in deeper water than the underlying Cornbrash Formation.

\section{Osgodby Formation, Red Cliff Rock Member}

526 Ripple cross-lamination and thin pale grey sand laminae in the lowermost part of the Osgodby Formation

527 indicate a shallowing environment as fine- to medium-grained sand was distributed offshore during storm

528 events. These primary sedimentary structures are, however, uncommon, as most of the sand/silt sediment has

529 been bioturbated by a variety of infaunal organisms (Fig.12). Relic sedimentary lamination is occasionally seen

530 as sand-dominated and mud-dominated units, c. $0.05 \mathrm{~m}$ thick (Fig. 12). Burrow traces are marked by pale grey,

531 relatively clean sand (burrow-fill) surrounded by zones and laminae of organic-rich sand (burrow wall). There is

532 a greater concentration of black pyrite ooids in the organic-rich laminae compared to the clean sand fraction 
533 (burrow-fill), suggesting a concentration and sorting of the pyrite ooids during the backfilling of the burrows.

534 Between 34.48 and $34.80 \mathrm{~m}$ depth in $\mathrm{BH}$ 1-3-03C, pale grey siderite nodules with dispersed pyrite ooids and

535 Rhizocorallium and Teichichnus burrows suggest slower sedimentation rates and longer residence time on the

536 sea floor. This level, at about $6 \mathrm{~m}$ above the base of the formation, may be equivalent to the coarser sandstone

537 unit and overlying $\beta 2$ unit illustrated for the Castle Hill section by Wright (1968, fig. 5), although that figure

538 shows these beds about 7 to $8 \mathrm{~m}$ above the base. In BH1-3-04 a distinctive white, fine-grained orthoquartzite

539 bed ( $0.10 \mathrm{~m}$ thick at $2.18 \mathrm{~m}$ above the base) has thin horizontal laminae with small pyrite ooids and ripple cross-

540 lamination at the base. This represents rapidly deposited storm sand with a highly mobile substrate that

541 prevented colonization by the ubiquitous burrowing organisms.

\section{$542 \quad$ Framboidal pyrite ooids}

543 Framboidal pyrite ooids have not been previously described from the Osgodby Formation, although berthierine

544 ooids were noted by previous authors (Wright 1968, 1977, 1978; Page in Cox \& Sumbler 2002). It is not certain

545 if the mineralogy of the ooids has been misidentified in hand specimen by previous workers, since all the black

546 ooids in the cores are pyritic. Pyrite ooids have concentric laminae, often, initiated around a quartz grain (Fig.

547 13). Individual lamina are thicker than those seen in the berthierine ooids of the Cornbrash Formation and the

548 Hackness Rock Member, and are composed of small pyrite clusters or framboids (Figs 13 and 14). The outer

549 cortex is often abraded or squeezed between adjacent surrounding quartz grains suggesting that the ooids were

550 relatively soft and deformable at the time of deposition. Sulphidic iron-rich mud, the precursor sediment of the

551 ooids, requires anoxic/reducing conditions to form, an environment very different from the oxygenated, storm-

552 deposited, quartz-rich sands indicated by the lower Osgodby Formation. An explanation for the concentric

553 nature of the pyrite ooids may be through the mechanism of a fluctuating redox interface in response to the

554 availability of organic carbon within anoxic muds (Pufahl \& Grimm 2003). Such redox-aggregated pyrite ooids

555 do not require mechanical rolling on the sea-floor as is the case with carbonate ooids. Pufahl \& Grimm (2003)

556 propose a mechanism whereby a concentric cortex of iron sulphide (composed of individual pyrite framboids) is

557 built around a grain, in situ, as the redox interface shifts up and down in response to biological oxygen demand

558 and the flux of organic carbon at the sediment-water interface. A similar accretionary, in situ origin was

559 proposed for berthierine ooids in the Middle Jurassic Eller Beck Formation (Knox 1969, 1970) and Lower

560 Jurassic ironstones (Taylor \& Curtis 1995). The origin of the pyrite ooids in the Osgodby Formation is

561 uncertain, but it is hypothesized that they developed in anoxic (reducing) conditions in shallow, muddy lagoons 
562

563

564

565

566

567

568

569

570

571

572

573

574

575

576

577

578

579

580

581

582

583

584

585

where there was abundant availability of organic matter (amorphous plant debris) (Taylor \& Curtis 1995; Taylor \& Macquaker 2000, 2011) in the nearshore coastal zone. Ooids were subsequently dispersed offshore along with quartz sand by during storm-surge events. This would account for the anomalous association of pyrite ooids in oxygenated sandy sediment, and would also explain the abraded nature of the outer cortex (Fig. 14). Sparse, stunted and thin-shelled bivalves and occasional belemnite guards in this member indicate highly mobile substrates that were inimical to bottom-dwelling shelly faunas, but the high proportion of amorphous organic matter favoured rapid colonization by sediment-ingesting ichnofauna.

\section{Osgodby Formation, Langdale Member}

The boundary between this unit and the underlying Red Cliff Rock Member is highly gradational, possibly due to reworking of Lower Callovian sands beneath the Middle Callovian beds (J. K. Wright pers.comm. 2015), and is tentatively taken at a gradational upward decrease in grain-size from $31.20 \mathrm{~m}$ to $29.00 \mathrm{~m}$ in BH1-3-03C.

Above this level, the Langdale Member is generally fine-grained, paler grey in colour, and is characterized by a lower proportion of amorphous organic matter. Pyrite ooids are uncommon. The upward increase in the proportion of vertically orientated burrows in the Langdale Member indicates a response of bottom-dwelling infauna to more frequent episodes of erosion and deposition, which caused organisms such as crustacea, bivalves and worms to move up and/or down in the sandy substrate in response to local scouring, erosion and deposition. Belemnite guards and thin-shelled bivalves are occasionally present. The uppermost $5 \mathrm{~m}$ are more intensively burrowed, with consecutive burrowing events illustrated as tier structures (Howard 1985; Gowland 1996; Taylor et al. 2003), with arrival first of the Chondrites organism, followed by Teichichnus, Siphonites and Diplocraterion or Rhizocorallium. The lower proportion of amorphous organic matter and absence of pyrite ooids compared to the Redcliff Rock Member suggests rising sea-level and blanketing of the forested coastal plain (hinterland) that provided abundant organic matter to the lower Osgodby sands. The carbonate content (cement) increases upward. Thin laminae with thin-shelled bivalves, brachiopods and wood fragments (drifted $\operatorname{logs})$ are present in the uppermost metre.

\section{Osgodby Formation, Hackness Rock Member}

The boundary between the Langdale and Hackness Rock members is relatively sharp and is generally marked by a shell bed (Fig. 16), above which the carbonate content, proportion of berthierine ooids and shelly fossils in the sandstone increase over an interval of about $0.30 \mathrm{~m}$. This upward-shallowing trend marks a regressive event through the late Athleta Zone and Lamberti Zone, a result of a global sea-level fall (Cox \& Sumbler 2002; 
591

592

593

594

595

596

597

598

599

600

601

602

603

604

605

606

607

608

609

610

611

612

613

614

615

616

617

618

619

Gradstein et al. 2012). In BH 2-3-01, the basal shell bed has a scoured, erosive base with bivalve escape structures above, followed by common Diplocraterion and Rhizocorallium burrows, suggesting a storm shelllag deposit followed by colonization of the substrate during waning current flow. This is overlain by bioturbated, berthierine-ooid rich, sandy limestone with abundant bivalves (e.g. Gryphaea, Ostrea), sparse brachiopods and serpulid worms, ammonites and belemnites (Fig. 16). Clusters of Gryphaea bivalves were seen in situ in the shaft excavation (Fig. 20). Berthierine ooids are often less concentrated in pale grey burrow-fill (e.g. Planolites, Thalassinoides, Teichichnus), indicating post-depositional sorting of the sediment.

The Hackness Rock Member represents a condensed sequence deposited in the near-shore zone, probably the upper shoreface, during a period of rising sea-level in the Late Callovian. This transgressive event cut off siliciclastic sediment supply, resulting in condensation of the sandy carbonate sediment. In contrast to the pyrite ooids seen in the lower Osgodby Formation, berthierine ooids were formed in oscillating tidal conditions on local highs and re-deposited in shallow depressions on the sea-floor (Williams 2002).

\section{Oxford Clay Formation, Weymouth Member}

The boundary between the Osgodby Formation and the Oxford Clay Formation is rarely seen at outcrop over the Cleveland Basin (but see Wright 1968). It marks the Callovian (Lamberti Zone)-Early Oxfordian (Mariae Zone) boundary at around $163.5 \mathrm{Ma}$ (Gradstein et al. 2012). In core, the boundary is sharp and the lowermost $0.15 \mathrm{~m}$ to $0.25 \mathrm{~m}$ of the Oxford Clay Formation is a grey and brownish grey siltstone with poorly contrasted burrowmottling, oysters and wood fragments, and dispersed small berthierine ooids (Fig. 20). The latter are interpreted as being reworked from the underlying Hackness Rock sands, but the presence of Planolites, Chondrites, Siphonites and Ophiomorpha burrows suggests a lower shoreface setting during the initial marine transgression. An interesting feature in the basal $0.06 \mathrm{~m}$ in $\mathrm{BH} 1-3-02$ and 2-3-01 is the presence of contorted, convolute laminae, possibly a result of rapid dewatering during the initial transgressive event. The proportion of berthierine ooids decrease upwards, and they are only rarely present $0.20 \mathrm{~m}$ above the base. Nektonic fauna represented by thin-shelled ammonites and belemnites indicates deeper-water conditions above the bioturbated base. Drifted wood fragments suggest a proximity to the shoreline. About $2 \mathrm{~m}$ above the base, there is a gradual change to light grey, blocky textured calcareous siltstone, but lacking depositional laminae. However, Pinna bivalves are preserved in-situ in the core and shaft. These siltstones have abundant, small-diameter, pyrite-filled burrows that form curved to sinuous traces parallel to bedding (Fig. 19), probably produced by worms feeding just below the sediment-water interface. 
621 blanketed much of the shallow-marine shoreface and lagoonal environments represented by the Hackness Rock

622 Member. The dinoflagellate cyst associations in the lower Oxford Clay Formation include cold water species

623 typical of the Boreal Realm such as Gonyaulacysta dentata, together with warmer water taxa such as

624 Scriniodinium crystallinum (Fig. 25). The presence of the latter may indicate an increase in thermal warming

625 following the marked global cooling event at the Callovian-Oxfordian transition (Poulsen \& Riding 2003; Dera

626 et al. 2011; Riding 2012; Riding \& Michoux 2013). This warming is believed to have caused the ocean water

627 expansion during the Mariae Zone that led to a global sea-level rise and associated widespread marine

628 transgression, which resulted in the extensive marine flooding of Callovian shelf environments.

629

630

\section{Regional context}

The Callovian to Oxfordian succession proved in the Toll House boreholes provides a useful analogue for studies of this interval in the Fulmar Formation (North Sea). The lower, middle and upper shoreface environments represented by the Osgodby Formation (Fig.26) show strong similarities with the Fulmar Formation of the Central North Sea Graben (Johnson et al. 1986), especially the Lower Fulmar Member (Donovan et al. 1993; Gowland 1996). In the Central Graben of the North Sea, the Lower Fulmar Member is lithologically very similar to the Osgodby Formation; shallow marine sandstones pass laterally to deeper water marine mudstones and turbidite lenses. Its base overlies fluviatile mudstones and sandstones (Pentland Formation) similar to the Scalby Formation onshore. Although the Cornbrash Formation is not described offshore, the Early Callovian marine transgression is marked by marine sandstones. Significantly, the internal lithofacies associations and trace fossil assemblages of the Lower Fulmar Member (Gowland 1996) are similar to those seen in the Toll House boreholes and shaft. Gowland's Facies Association D, interpreted as representing 'Distal lower shoreface/proximal offshore transition', is similar to that in the lower Osgodby Formation (Red Cliff Rock Member), and passes upwards to Facies Association C, representing 'Bioturbated lower shoreface', seen onshore in the overlying Langdale Member. The condensed berthierine ooidal sequence (Hackness Rock Member) is not represented in the Lower Fulmar Member offshore, presumably because of greater tectonically induced subsidence rates in the Central Graben, but some lithofacies elements onshore are similar to Facies Association C (bioturbated lower shoreface), especially the presence of granule/pebble lags, shell coquinas (including thick shelled oysters) and deep-tier reworking by Ophiomorpha (crustacean) burrows. In the Central Graben, the transition from shallow marine sandstone to marine mudstone (cf. the Osgodby 

comparison to the Mariae Zone event seen onshore.

651

652

653

654

655

656

657

658

659

660

661

662

663

664

665

666

667

668

669

670

671

672

673

674

675

\section{Structural geology}

As noted above, the Castle Hill outlier is bounded to the west by major extensional normal faults interpreted as part of the onshore-offshore Peak Fault system (Milsom \& Rawson 1989; Rawson \& Wright 2000, fig. 2).

\section{Toll House Fault}

The presence of this major fault was proved during shaft excavation to cut a narrow sector of the eastern side of the shaft from c. $-14 \mathrm{~m}$ OD to $-20 \mathrm{~m}$ OD. At $-14 \mathrm{~m}$ OD the fault is expressed by the contrast between extensively burrow-mottled, fine- to medium-grained sandstone (Osgodby Formation) on the upthrow side of the shaft, with medium grey calcareous siltstone (Oxford Clay Formation) on the downthrow side (Figs 21, 22). Fracturing within the harder Osgodby Formation adjacent to the fault was shown by orange and brown oxidative weathering of the ferruginous sandstone. The Oxford Clay Formation at this level yielded fragmentary Lower Oxfordian ammonites that confirmed the presence of the fault.

Deepening of the shaft to $-17 \mathrm{~m}$ depth confirmed the presence of the fault downthrowing both the Oxford Clay Formation and the Hackness Rock Member against the Osgodby Formation (Fig. 22). The orientation of the fault trace in the bottom of the shaft is between $350^{\circ} \mathrm{N}$ and $010^{\circ} \mathrm{N}$, based on a theodolite survey at the base of the shaft; the co-ordinates for the fault trace are between $\left[{ }^{5} 05213.0033,{ }^{4} 88929.706\right]$ and $\left[{ }^{5} 05207.757\right.$, $\left.{ }^{4} 88918.890\right]$ (Helen Miles (Arup) pers. comm. 2013). The Hackness Rock, at this depth, is highly fractured with abundant calcite mineralization along the fracture/fault planes. Pyrite crystals are also present. Sub-vertical fracture/fault plane surfaces of the blue-grey, berthierine ooidal sandstone are weathered (oxidized) to orange, brown and yellow as a result of the flow of brackish water along the fractures. Sparse ammonites were collected from the Hackness Rock Member at this level. On the side of the shaft opposite the fault trace, the middle to lower part of the Osgodby Formation sandstone was seen dipping at about $22^{\circ}$ to $110^{\circ} \mathrm{N}$, i.e. dipping at approximately right angles to the fault (Fig. 22). The anomalously high dip is attributed to localized drag of the upthrow (footwall side) of the fault. Downthrow of the Hackness Rock Member marker bed seen on opposite sides of the fault, as seen at $-1.5 \mathrm{~m}$ depth (upthrow) and at $-17 \mathrm{~m}$ depth (downthrow), gives an approximate throw of $15.5 \mathrm{~m}$ to the east. 
The Toll House Fault is an important discovery that helps our interpretation of the geological structure of the

678 area (Fig. 1). The eastward plunge of the shallow Castle Hill syncline (Fig. 1) is probably due to easterly fault drag on the Toll House Fault. Furthermore, the new fault explains the anomalously high structural dip seen in the extant Hackness Rock Member outcrop at South Toll House Cliff (Fig. 2), again a result of local fault drag related to this fault. At $-17 \mathrm{~m} \mathrm{OD}$ in the shaft, the dip increased up to $20^{\circ}$ towards $110^{\circ} \mathrm{N}$ within the Osgodby Formation (footwall side) (Fig. 22), in close proximity to the fault. Calcite and pyrite mineralization along fractures adjacent to the fault suggest ancient movement, possibly related to the Neogene 'Alpine' orogeny and basin inversion (Hemingway \& Ridler 1982). Fault drag, at approximately right angles to the fault trace, suggests dip-slip (normal) faulting rather than strike-slip displacement. Offshore from the Yorkshire coast, Milsom \& Rawson (1989) showed that fault movement within the Peak Trough occurred from Triassic through to Neogene times. There may have been synsedimentary Jurassic movement on the Toll House Fault, but this was not proven in this study. The Toll House Fault is interpreted as a splay fault branching off the main Castle Hill Fault, the latter marking the western bounding fault of the Peak Trough. The eastern bounding fault is the Red Cliff Fault (downthrow west), which is seen in Cayton Bay and then trends NNW offshore from Castle Hill (Powell \& Reay 1982).

\section{Geomorphology}

The geomorphology of Castle Hill is also controlled to some extent by the Toll House Fault. The Castle Hill outlier forms a promontory chiefly as a result of the hard, resistant nature of the Corallian Group (sandy limestones) cap-rock downfaulted against the less resistant Ravenscar Group rocks (mudstones and poorly cemented sandstones). However, the Toll House Fault must have controlled the eastern cliff edge during sealevel rise during the late Quaternary to Holocene. The harder Hackness Rock Member would have been exposed on the downthrow (seaward) side of the lower cliff and foreshore, thereby protecting the Castle Hill promontory from marine erosion during rising sea-levels.

\section{Conclusions}

Study of the Toll House site investigation borehole cores, gamma-ray logs and shaft geology has provided new data on the Callovian to Lower Oxfordian succession, only part of which is exposed in the South Toll House Cliff Geological Site of Special Scientific Interest (SSSI). The value of the geological findings is both of scientific and historical value, because the lower part of the succession investigated by pioneering Victorian 
geologists on the lower foreshore has not been visible since the construction of Marine Drive (1897-1907) and more recent rock-armouring of the foreshore.

The full Lower Callovian to Lower Oxfordian succession was proved in boreholes, represented, in downward sequence, by the lower part of the Lower Oxfordian Oxford Clay Formation (Weymouth Member); Callovian Osgodby Formation, including the Hackness Rock, Langdale and Red Cliff Rock members; the Lower Callovian Cayton Clay and Cornbrash formations; and the uppermost Bathonian Scalby Formation. The upper part of the Lower Callovian to Lower Oxfordian succession, down to the level of the Red Cliff Rock Formation, was proven in the Toll House shaft excavation to -20 m OD depth.

The Osgodby Formation is interpreted as a bioturbated, lower to upper shoreface, silty sandstone, similar in lithofacies to the Lower Fulmar Member of the Central Graben, North Sea. It overlies a condensed transgressive Early Callovian marine succession, comprising the Cornbrash Formation below and the attenuated Cayton Clay Formation above. The marine transgression flooded the low gradient alluvial plain of the underlying Scalby Formation (Long Nab Member). The presence of latest Bathonian to Early Callovian palynofloras in the uppermost Scalby Formation indicates that there was no great time gap between the deposition of this paralic unit and the overlying marine Cornbrash Formation.

Condensed sequences, deposited during marine transgressions, rich in berthierine (iron silicate) ooids and abundant shelly fossils that include oysters, ammonites and belemnites, are represented by the Cornbrash Formation and Hackness Rock Member, at the base and top of the Callovian succession respectively. The intervening Osgodby Formation sandstone (Red Cliff Rock and Langdale members) is extensively bioturbated with virtual destruction of primary sedimentary structures by a diverse ichnofauna (trace fossil) assemblage that scavenged the sandy substrate rich in amorphous organic matter. Sedimentation rates were slow, with long sediment residence time on the sea-floor resulting in a high bioturbation index. Newly recorded pyrite ooids in the lower Osgodby Formation sandstones are interpreted as having been formed in anoxic lagoons in the nearshore zone as a result of a fluctuating redox interface. Ooids were subsequently swept offshore during storm surge-ebb events to be deposited on the lower shoreface along with bi-modal quartz sand. dentata and Wanaea fimbriata confirm the earliest Oxfordian age indicated by the presence of the zonal ammonite Quenstedoceras mariae in the lowermost siltstone. Warm water dinoflagellate cysts of presumed Tethyan affinity in the lower part of the Oxford Clay Formation, such as Scriniodinium crystallinum, are also 
consistent with the Early Oxfordian age. These thermophylic taxa may indicate warming that gave rise to marine water expansion during the Mariae Zone, and which led to a global sea-level rise and hence a widespread marine transgression.

Shaft excavations revealed a new major fault, the Toll House Fault, trending $c .350^{\circ} \mathrm{N}$ and downthrowing the Hackness Rock Member about $15.5 \mathrm{~m}$ to the east. The fault appears to control the eastern side of Castle Hill and is responsible for the anomalously high dip in the South Toll House Cliff SSSI due to local fault drag. The Toll House Fault is interpreted to be a splay fault branching off the main Castle Hill Fault, and together they form the western bounding faults of the Peak Trough that extends northwards offshore. Faulting along Marine Drive, parallel to the cliff, may explain some of the anomalies between the stratigraphy seen in the borehole cores and that reconstructed from Victorian records of the formerly exposed lower cliff and foreshore.

\section{Acknowledgements and Funding}

We are grateful to Tom Casey, Arup, for initiating the project throughYorkshire Water, advising on the engineering geology and for providing geophysical logs of the boreholes. Helen Miles, Arup, is thanked for arranging and supervising site visits, collecting and photographing bagged samples in the shaft. We are grateful to Dr Andy Howard and Jon Ford (BGS) for reviewing the original report and advising on Jurassic trace fossil assemblages. We thank Dr Beris Cox for identifying the macrofossils, especially ammonites, from the boreholes and shaft. Giuseppe La Vigna, Site Agent, Morgan Sindall Gronmij, arranged access to the site and H\&S briefings. Engineers and contractors at Ward Burke are thanked for supervising H\&S in the shaft. We are grateful to Dr Stuart Gowland, Ichron Ltd, for information on Jurassic trace fossils and to Peter Smith for permission to use Figure 1. We thank Paul Witney (BGS) for digital photography of the core and the BGS Core Store team for delivery of the core to BGS and core slabbing. Thanks go to Caron Simpson and Ian Longhurst for preparing the figures. Dr Ian P. Wilkinson (BGS) kindly identified the foraminifera in the Hackness Rock. JHP's contribution to this paper was completed while he was an Honorary Research Associate of the British Geological Survey, and the authors publish with the approval of the Executive Director, British Geological Survey (NERC). Finally, we are indebted to Professor J K Wright and an anonymous reviewer for their helpful constructive comments on the manuscript, and to Dr Stewart Molyneux for his editorial guidance.

\section{Scientific editing by Stewart Molyneux}

\section{REFERENCES}


Arkell, W. J. 1933. The Jurassic system in Great Britain. Clarendon Press, Oxford.

Arkell, W.J. 1945. The zones of the Upper Jurassic in Yorkshire. Proceedings of the Yorkshire Geological Society, 25, 339-359.

Berger, J.-P. 1986. Dinoflagellates of the Callovian-Oxfordian boundary of the "Liesberg-Dorf" quarry (Berner Jura, Switzerland). Neues Jahrbuch für Geologie und Paläontologie Abhandlungen, 172, 331-355.

Brinkmann, R. 1926. Über die sedimentare Abbildung epiogener Beuvegung sonie uber das Schichtungsproblem. Nachrichten von der Gesellschaft der Wissenschaften zu Göttingen, Mathematischphysikalische Klasse, 1925, 199.

British Geological Survey 1998a. Whitby and Scalby. England and Wales Sheet 35 \&44. Solid and Drift Geology. 1:50 000 Provisional Series. British Geological Survey, Keyworth, Nottingham.

British Geological Survey 1998b. Scarborough. England and Wales Sheet 54. Solid and Drift Geology. 1:50 000 Provisional Series. British Geological Survey, Keyworth, Nottingham.

Buckman, S.S. 1909-1930. Yorkshire type ammonites, vols I, II, 1909-1919. Type ammonites, vols III-VII, 1919-1930. Printed privately, London.

Buckman, S.S. 1913. The 'Kelloway Rock' of Scarborough. Quarterly Journal of the Geological Society of London, 69, 152-168.

Cope, J.C.W., Duff, K.L., Parsons. C.F., Torrens, H.S., Wimbledon, WA. \& Wright, J.K. 1980. A correlation of Jurassic rocks in the British Isles. Part Two: Middle and Upper Jurassic. Geological Society of London Special Report, No. 15, 109 pp.

Cox, B. M, 1988. English Callovian (Middle Jurassic) Perisphinctid Ammonites, Part 1, Monographs of the Palaeontological Society, No. 575 (part of Volume 140 for 1986), Palaeontographical Society, London.

Cox, B. M., Hudson, J. D. \& Martill, D. M. 1993. Lithostratigraphic nomenclature of the Oxford Clay (Jurassic). Proceedings of the Geologists’ Association, 103 [for 1992], 343-345.

Cox, B. M. \& Sumbler, M. G. 2002. British Middle Jurassic Stratigraphy. Joint Nature Conservation Committee. Geological Conservation Review Series, 26.

Dera, G., Brigaud, B., Monna, F., Laffont, R., Pucéat, E., Deconinck, J.-F., Pellenard, P., Joachimski, M.M. \& Durlet, C. 2011. Climatic ups and downs in a disturbed Jurassic world. Geology, 39, 215-218.

Donovan, A.D., Djakic, A.W., Ioannides, N.S., Garfield, T.R. \& Jones, C.R. 1993. Sequence stratigraphic control on the Middle and Upper Jurassic reservoir distribution within the UK Central North Sea. In: 

Geological Society, London, 251-269.

Fox-Strangways, C. 1892. Jurassic rocks of Britain, Vols. 1 and 2, Yorkshire. Memoir of the Geological Survey of Great Britain.

Fox-Strangways, C. \& Barrow, G. 1915. The geology of the country between Whitby and Scarborough. Memoir of the Geological Survey of Great Britain (2nd edition).

Gowland, A.S. 1996. Facies characteristics and depositional models of highly bioturbated shallow marine siliciclastic strata: an example from the Fulmar Formation (late Jurassic), UK Central.Graben. In: Hurst, A. et al. (eds), Geology of the Humber Group: Central Graben and Moray Firth, UKCS. Geological Society Special Publications, 114, 185-214.

Gradstein, F. M. Ogg, J. G. Schmitz, M. \& Ogg, G. 2012. The Geologic Time Scale 2012. Elsevier.

Hemingway, J.E. \& Riddler, G.P. 1982. Basin inversion in north Yorkshire. Transactions of the Institute of Mining and Metallurgy, Section B, 91, 175-186.

Howard, A.S. 1985. Ichnofacies and depositional environments of the Fulmar Formation (U. Jurassic) in the Gannet and Kittiwake fields, central North Sea, Stratigraphy and Sedimentology Research Group, Report No. CS24/85/10 for BGS Hydrocarbons (Offshore) Research Programme. pp.18 +figs and plates.

Huddleston, W.H.1876. The Yorkshire Oolites. Part 2: The Middle Oolites . Proceedings of the Geologists' Association, 4, 353-410.

Johnson, H.D., MacKay, T.A. \& Stewart, D.J. 1986. The Fulmar Oil-field (Central North Sea): geological aspects of its discovery, appraisal and development. Marine and Petroleum Geology, 3, 99-125.

Knox, R.W.O'B. 1969. Sedimentological studies of the Eller Beck Bed and Lower Deltaic series in north-east Yorkshire. Unpublished thesis, University of Newcastle-upon- Tyne.

Knox, R.W.O'B. 1970. Chamosite ooliths from the Winter Gill Ironstone (Jurassic) of Yorkshire (England). Journal of Sedimentary Petrology, 40, 1216-1225.

Leckenby, J. 1859. On the Kelloway Rock of the Yorkshire Coast. Quarterly Journal of the Geological Society of London, 15, 4-15. and the evidence for late Bajocian/Bathonian uplift of the Yorkshire Basin. Proceedings of the Yorkshire Geological Society, 42, 461-482. 
Milsom, J. \& Rawson, P. F. 1989. The Peak Trough - a major control on the geology of the North Yorkshire coast. Geological Magazine, 126, 699-705.

Page, K.N. 1989. A stratigraphic revision for the English Lower Callovian. Proceedings of the Geologists' Association, 100, 363-382.

Page, K N 1991. Ammonites. pp. 86-143 in Fossils of the Oxford Clay. Palaeontological Association Field Guide to Fossils: Number 4.

Phillips, J. 1829-32. Illustrations of the geology of Yorkshire, or a description of the strata and organic remains. Part 1. The Yorkshire Coast. Privately printed, York.

Poulsen, N.E. \& Riding, J.B. 2003. The Jurassic dinoflagellate cyst zonation of Subboreal Northwest Europe. In: Ineson, J.R. \& Surlyk, F. (eds) The Jurassic of Denmark and Greenland. Geological Survey of Denmark and Greenland Bulletin, 1, 115-144.

Powell, J H. 1980. Preliminary report on the geological structure and stratigraphy of the area offshore from Castle Hill and Scalby Ness. Report to Babtie, Shaw \& Morton, consultants to the Yorkshire Water Authority.17pp

Powell, J.H. 2010. Jurassic sedimentation in the Cleveland Basin: a review. Proceedings of the Yorkshire Geological Society, 58, 21-72.

Powell, J H \& Reay, D M. 1982. Preliminary interpretation report on the geological structure and stratigraphy of the area offshore from Castle Hill, Scarborough. IGS Continental Shelf Division, Marine Geophysics Unit, Report No. UC/026. 9pp.

Powell, J H \& Riding, J B. 2013. Scarborough Geological Watching Brief; Toll House Shaft Site, Castle Hill SSSI. British Geological Survey Internal Report, IR/13/025, 48 pp + figures.

Prauss, M. 1989. Dinozysten-stratigraphie und Palynofazies im Oberen Lias und Dogger von NW-Deutschland. Palaeontographica Abteilung B, 214, 1-124.

Pufahl, P. K. \& Grimm, K.A. 2003. Coated phosphate grains: proxy for physical, chemical and ecological changes in seawater. Geology, 31, 801-804.

Rawson, P. F. \& Wright, J. K. 2000. The Yorkshire Coast. Geologists' Association Guide No. 34. 3rd Edition. The Geologists' Association.

Riding, J.B. 1982. Jurassic dinocysts from the Warboys Borehole, Cambridgeshire, England. Journal of Micropalaeontology, 1, 13-18. 
Riding, J.B. 1987. Dinoflagellate cyst stratigraphy of the Nettleton Bottom Borehole (Jurassic: Hettangian to Kimmeridgian), Lincolnshire, England. Proceedings of the Yorkshire Geological Society, 46, 231-266.

Riding, J.B. 1992. On the age of the Upper Ostrea Member, Staffin Bay Formation (Middle Jurassic) of northwest Skye. Scottish Journal of Geology, 28, 155-158.

Riding, J.B. 2005. Middle and Upper Jurassic (Callovian to Kimmeridgian) palynology of the onshore Moray Firth Basin, northeast Scotland. Palynology, 29, 87-142.

Riding, J.B. 2012. The Jurassic dinoflagellate cyst Gonyaulacysta dentata (Raynaud 1978) Lentin \&Vozzhennikova 1990 emend. nov.: an index species for the Late Callovian to earliest Oxfordian of the northern hemisphere. Review of Palaeobotany and Palynology, 176-177, 68-81.

Riding, J.B. \& Thomas, J.E. 1992. Dinoflagellate cysts of the Jurassic System. In: Powell, A.J. (ed.). A stratigraphic index of dinoflagellate cysts. British Micropalaeontological Society Publications Series. Chapman and Hall, London, 7-97.

Riding, J.B. \& Thomas, J.E. 1997. Marine palynomorphs from the Staffin Bay and Staffin Shale formations (Middle-Upper Jurassic) of the Trotternish Peninsula, NW Skye. Scottish Journal of Geology, 33, 59-74. Riding, J.B. \& Wright, J.K. 1989. Palynostratigraphy of the Scalby Formation (Middle Jurassic) of the Cleveland Basin, north-east Yorkshire. Proceedings of the Yorkshire Geological Society, 47, 349-354. Riding, J.B. \& Michoux, D. 2013. Further observations on the Jurassic dinoflagellate cyst Gonyaulacysta dentata (Raynaud 1978) Lentin \& Vozzhennikova 1990 emended Riding 2012. Review of Palaeobotany and Palynology, 196, 51-56.

Riding, J.B., Fedorova, V.A. \& Ilyina, V.I. 1999. Jurassic and lowermost Cretaceous dinoflagellate cyst biostratigraphy of the Russian Platform and northern Siberia, Russia. American Association of Stratigraphic Palynologists Contributions Series, No. 36, 179 pp.

Sarjeant, W.A.S. 1959. Microplankton from the Cornbrash of Yorkshire. Geological Magazine, 96, 329-346.

Taylor, A.M. \& Gawthorpe, R.L., 1993. Applications of sequence stratigraphy and trace fossil analysis to reservoir description: examples from the Jurassic of the North Sea. In: Parker, J.R. (ed.), Petroleum Geology of Northwest Europe: Proceedings of the 4th Conference. Geological Society, London, pp. $317-$ 335.

Taylor, A.M, Goldring, R. \& Gowland, S. 2003. Analysis and application of ichnofabrics. Earth-Science Reviews, 60, 227-259. 
Taylor, K.G. \& Macquaker, J.H.S. 2000. Early diagenetic pyrite morphology in a mudstone-dominated succession: the Lower Jurassic Cleveland Ironstone Formation, eastern England, $\quad$ 131, 77-86.

Taylor, K.G. \& Macquaker, J.H.S. 2011. Iron in Earth systems: Iron minerals in marine sediments record chemical environments. Elements, 7, 113-118.

Taylor, K.G. \& Curtis, C.D. 1995. Stability and facies association of early diagnetic mineral assemblages: an example from a Jurassic ironstone-mudstone succession, U.K. Journal of Sedimentary Research, Section A: Sedimentary Petrology and Processes, 64, 358-368.

Whyte, M.A. \& Romano, M. 2006. Middle-Upper Jurassic sequence between Cayton Bay and Yons Nab. In: Scrutton, C.T. \& Powell, J.H. (eds) Yorkshire Rocks and Landscapes - A Field Guide, 3rd Edition, Yorkshire Geological Society, pp. 174-182.

Williams, M.E. 2002. Lateral variation within a hiatal-condensed bed and the controls on the formation and occurrence of berthierine ooids: a case study from the Middle Jurassic of NE England, UK. Geological Journal, 37, 279-296.

Woollam, R. 1980. Jurassic dinocysts from shallow marine deposits of the East Midlands, England. Journal of the University of Sheffield Geological Society, 7.5, 243-261.

Wright, J.K. 1968. The stratigraphy of the Callovian Rocks between Newtondale and the Scarborough Coast, Yorkshire. Proceedings of the Geologists’ Association, 79, 363-399.

Wright, J.K. 1977. The Cornbrash Formation (Callovian) in North Yorkshire and Cleveland. Proceedings of the Yorkshire Geological Society, 41, 325-346.

Wright, J.K. 1978. The Callovian succession (excluding Cornbrash) in the western and northern parts of the Yorkshire Basin. Proceedings of the Geologists' Association, 89, 259-261.

Wright, J.K. 1983. The Lower Oxfordian (Upper Jurassic) of North Yorkshire. Proceedings of the Yorkshire Geological Society, 44, 249-281.

Wright, T. 1860. On the subdivisions of the Inferior Oolite in the south of England, compared with equivalent beds of that Formation on the Yorkshire coast. Quarterly Journal of the Geological Society of London, 16, $1-48$.

Young, G. \& Bird, J. 1822. A geological survey of the Yorkshire coast. Clark, Whitby, iv +322 pp. 